\title{
Two species of antiganglioside antibodies in a patient with a pharyngeal-cervical-brachial variant of Guillain-Barré syndrome
}

\author{
Kouichi Mizoguchi, Asako Hase, Tomokazu Obi, Hiroaki Matsuoka, Masami Takatsu, \\ Yoshirou Nishimura, Fumitoshi Irie, Yousuke Seyama, Yoshio Hirabayashi
}

\begin{abstract}
A patient with a pharyngeal-cervicalbrachial variant of Guillain-Barré syndrome had anti-GT1a and anti-GD1a antibodies (IgG) in the serum. The activities of anti-GT1a antibodies were stronger than anti-GD1a antibodies and their activities declined later in the clinical course. These two different antibodies bound independently to each ganglioside in an absorption study with polystyrene beads coated with GT1a or GD1a.
\end{abstract}

(F Neurol Neurosurg Psychiatry 1994;57:1121-1123)

Antiganglioside antibodies have been detected in patients with Guillain-Barré syndrome, ${ }^{12}$ although it is not clear whether they have a specific role in the pathogenesis of Guillain-Barré syndrome. Here we report a patient with a pharyngeal-cervical-brachial variant of Guillain-Barré syndrome, who had two antibodies in his serum, one against GT1a, a minor ganglioside species, and the other against GD1a.

Department of
Neurology, National Shizuoka Hospital

24-1 Joto-cho,

Shizuoka 420, Japan

$\mathrm{K}$ Mizoguchi

A Hase

T Obi

H Matsuoka

M Takatsu

Y Nishimura

Laboratory for Glyco

Cell Biology, Frontier

Research Program,

The Institute of

Physical and

Chemical Research

(RIKEN). 2-1

Hirosawa, Wako

351-01, Japan

F Irie

Y Hirabayashi

Department of

Physiological

Chemistry and

Nutrition, Faculty of

Medicine, The

University of Tokyo,

Hongo, Bunkyo-ku,

Tokyo, Japan

F Irie

Y Seyama

Correspondence to

Dr Kouichi Mizoguchi.

Received 7 September 1993

and in final revised form

1 March 1994.

Accepted 8 March 1994

\section{Case report}

A forty year old man was admitted for dysphagia on 25 June 1991. He had been treated with phenytoin and phenobarbitone for epilepsy since he was 18 years old. From 6 June, he experienced diarrhoea two or three times a day. He had difficulty in swallowing on 22 June. On the next day, he felt weakness in his neck and both upper limbs. The day before admission, weakness of the proximal regions of both lower limbs developed.

On admission, weakness of the bilateral facial muscle, dysphagia, and dysarthria were present. The strength of neck flexion and the upper limbs were $3 / 5$ (MRC grade), and 4/5 in the lower limbs. Gripping strength was $7 \mathrm{~kg}$ on the right and $0 \mathrm{~kg}$ on the left. Deep reflexes were normal and pathological reflexes were not elicited. Sensory disturbance and ataxia were not seen. Routine laboratory examinations were normal, including complete blood count, blood chemistries, and immunological examinations. Protein concentration in CSF was $350 \mathrm{mg} / \mathrm{l}$ with normal cellularity. Stool culture was negative for
Clostridium jejuni. Motor nerve conduction velocities were normal in the right median, ulnar, and peroneal nerves, but compound muscle action potentials were $2.01 \mathrm{mV}$ at the proximal and $4.39 \mathrm{mV}$ at the distal portion of the ulnar nerve, and $0.366 \mathrm{mV}$ and $0.834 \mathrm{mV}$ in the peroneal nerve, respectively. $F$ Waves of the right median and ulnar nerves had normal latencies, but could not be elicited in the right peroneal nerve.

Three days after admission, diplopia appeared with aggravated weakness of facial and limb muscles. He was treated with double filtration plasmapheresis on the $7 \mathrm{th}, 9 \mathrm{th}$, $11 \mathrm{th}, 14 \mathrm{th}$, and $16 \mathrm{th}$ days. The strength of all limbs, but not facial and neck muscles, improved to $4-5 / 5$ with grip strength of $9 \cdot 5$ $\mathrm{kg}$ in the right and $6.0 \mathrm{~kg}$ in the left after plasmapheresis. Deep reflexes were slightly exaggerated. Protein concentration in CSF was normal on the 52nd day. Follow up motor nerve conduction velocity studies showed that compound action potentials of the ulnar and peroneal nerves were normalised by the 24 th day. He was discharged 60 days after admission with almost full recovery except for the facial and neck muscles. The strength of his neck muscles had fully recovered by three months and his facial muscles by six months after discharge.

\section{Methods}

ENZYME LINKED IMMUNOSORBENT ASSAY (ELISA)

Antigenic gangliosides, which included GM3, GM2, GM1a, GD1a, GD1b, GT1b, and GQ1b, were prepared from bovine brains by $\mathrm{Q}$ sepharose column chromatography according to the method of Hirabayashi et al. ${ }^{3}$ GT1a was a gift from $\operatorname{Dr} S$ Ando (Tokyo Metropolitan Institute of Gerontology).

The ELISA was carried out by the method of Higashi et al. ${ }^{4}$ The antigenic solution contained $20 \mathrm{pmol}$ of each ganglioside. After blocking with $5 \%$ bovine serum albuminphosphate buffered saline (BSA-PBS), triplicate samples of serum were diluted 1:100 with $0 \cdot 25 \%$ BSA-PBS and incubated for two hours at room temperature. Goat anti-human IgM or IgG antibody conjugated to horse radish peroxidase (Jackson Immunoresearch Laboratories, Inc, West Grove, PA, USA) diluted 1:1000 with $0 \cdot 25 \%$ BSA-PBS was 
added as secondary antibody and incubated for two hours at room temperature. After further incubation with $50 \mu \mathrm{l} 0 \cdot 1 \% o$-phenylenediamine and $0.02 \% \mathrm{H}_{2} \mathrm{O}_{2}$ in $0.2 \mathrm{M}$ sodium citrate buffer for 15 minutes at room temperature, the enzyme reaction was stopped by adding $50 \mu \mathrm{l}$ of $1 \mathrm{~N} \mathrm{HCl}$ and measured with a microplate spectrophotometer at $492 \mathrm{~nm}$.

\section{ABSORPTION STUDY}

An absorption study was performed with GT1a or GD1a coated polystyrene beads as follows: a total of $2.5 \mathrm{mg}$ of polystyrene beads (MW 50 000, Polysciences Inc) was added to $1 \mathrm{ml}$ of chloroform-methanol solution (2:1 $\mathrm{v} / \mathrm{v}$ ), containing $1 \mathrm{mg}$ of GT1a or GD1a. The solution was dried by rotary evaporator and the beads were suspended in $5 \mathrm{ml}$ PBS. The patient's serum, diluted at $1: 50$ with $0.25 \%$ BSA-PBS, was mixed with the same volume of PBS containing GT1a or GD1a coated polystyrene beads. The solution was incubated at $37^{\circ} \mathrm{C}$ for 30 minutes, centrifuged at $3000 \mathrm{rpm}$ for 15 minutes, and the supernatant was used as the primary antibody for ELISA. As a control, PBS was used instead of GD1 a coated polystyrene beads.

\section{Results}

We detected anti-GT1a and anti-GDla IgG antibodies in this patient's serum. Antibody activities against the other gangliosides used in this study could not be detected. AntiGT1a antibodies reacted more strongly than anti-GD1a antibodies (figure). Both antiGT1a and -GD1a antibodies showed their highest activities on the 2 nd day after admission, declined with clinical course, and could not be detected after six months (figure).

In the absorption study, when the patient's serum was preincubated with GT1a coated polystyrene beads, anti-GT1a antibody was absorbed on to the beads, but anti-GD1a antibody activities did not decrease. On the other hand, the activities of anti-GT1a antibody did not decrease when the patient's serum was preincubated with GD1a coated polystyrene beads or only with PBS.

We also detected anti-GMla IgG antibodies in two of seven typical patients with Guillain-Barré syndrome, anti-GQ1b and anti-GT1a IgG antibodies in all eight patients

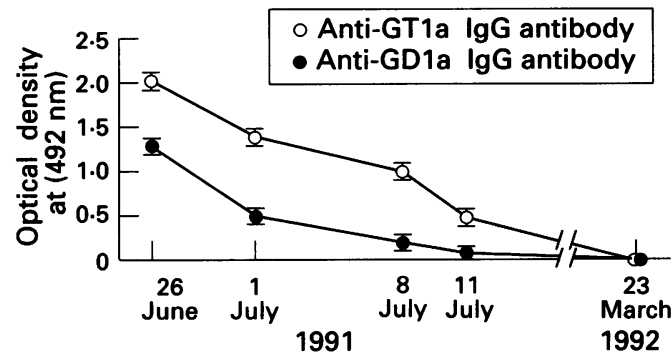

Activities of anti-GT1a and -GDIa IgG antibodies of this patient. Open circles indicate the activity of anti-GT1a IgG antibody and closed circles that of anti-GDIa IgG antibody. The serum and primary antibodies were diluted $1: 100$. with Miller-Fisher syndrome tested, and IgM antibodies against polysialogangliosides in a patient with macroglobulinaemia and sensory dominant neuropathy. ${ }^{7}$ No IgG or IgM antibody activities against the eight gangliosides used in this study were detected in the serum of the other patients-namely, those with amyotrophic lateral sclerosis $(n=33)$, multiple sclerosis $(n=3)$, myasthenia gravis $(n=$ 12), and other neurological diseases ( $n=$ 154), or normal controls at a dilution of $1: 100$.

\section{Discussion}

In 1986, Ropper reported three patients who, like ours, developed prominent weakness of the pharyngeal-cervical-brachial regions without either lower limb weakness or sensory disturbance, and labelled it "pharyngealcervical-brachial weakness resembling botulism or diphtheria". ${ }^{5}$ Conduction block in the ulnar and peroneal nerves in our patient was compatible with postinfectious demyelinating polyneuropathy.

From our results it is suggested that the detected antibodies, anti-GT1a and antiGD1a, participated in the pathological process of this patient, and that these two different antibodies independently reacted with GT1a and GD1a. Ilyas et al detected two kinds of anti-ganglioside antibodies in two patients with Guillain-Barré syndrome. ${ }^{1}$ Their antibodies, however, reacted with the common structure of GD1a and GT1b, GalNAc-Gal-NeuAc-NeuAc. To our knowledge, there is no other report of a patient who has two antibodies reacting independently with a different ganglioside without sharing a common structure.

Anti-GDla antibody was reported in patients with Guillain-Barré syndrome by Ilyas et $a l^{1}$ and Yuki et al. ${ }^{2}$ These antibodies were also detected in a patient with motor neuropathy with monoclonal IgM protein.? On the other hand, the existence of antiGT1a IgG antibodies was reported in patients with Miller-Fisher syndrome, although such patients mostly have antiGQ1b IgG antibodies. ${ }^{8}$ GT1a was first detected in the human brain by Ando et al, ${ }^{9}$ and later in the human spinal $\operatorname{cord}^{10}$ and cauda equina. ${ }^{11} \mathrm{GT} 1 \mathrm{a}$ is a minor ganglioside, forming $1.8 \%$ of the total gangliosides of human cerebral white matter, $2 \cdot 2 \%$ of human cerebral grey matter, and $0.5 \%$ of the human spinal cord, respectively. ${ }^{12}$

We thank Dr S Ando (Tokyo Metropolitan Institute of Gerontology) for his gracious gift of GT1a.

1 Ilyas AA, Willison HJ, Quarles RH, Jungalwala FB, Cornblath DR, Trapp BD, et al. Serum antibodies to gangliosides in Guillain-Barré syndrome. Ann Neurol 1988;23:440-7.

2 Yuki N, Yoshino H, Sato S, Shinozawa K, Miyatake T. Severe acute axonal form of Guillain-Barré syndrome associated with IgG anti-GDla antibodies. Muscle Nerve 1992;15:899-903.

3 Hirabayashi $Y$, Nakao T, Matsumoto M. Improved method for large-scale purification of brain gangliosides by $\mathrm{O}-\mathrm{Sepharose}$ column chromatography. Immunoby Q-Sepharose colunn chios polysialogangliosides in adult bovine brains. $f$ Chromatogr 1988;445:377-84. 
4 Higashi H, Ikuta K, Ueda S, Kato S, Hirabayashi Y, Matsumoto $M$, Naiki $M$. Characterization of $\mathrm{N}$-glycolylneuraminic acid containing glycosphingolipids from a Marek's disease lymphoma-derived chicken cell line, MSB1, as tumor-associated heterophile HanganutziuDeicher antigens. $\mathcal{F}$ Biochem (Tokyo) 1984;95:785-94.

5 Ropper AH. Unusual clinical variants and signs in Gupper AH. Unusual clinical variants and signs in

6 Obi T, Kusunoki S, Takatsu M, Mizoguchi K, Nishimura Y. IgM M-protein in a patient with sensory dominant neuropathy binds preferentially to polysialogangliosides. Acta Neurol Scand 1992;86:215-8.

7 Bollensen E, Schipper HI, Steck AJ. Motor neuropathy with activity of monoclonal IgM antibody to GD1a ganglioside. I Neurol 1989;236:353-5.
8 Chiba A, Kusunoki S, Obata H, Machinami R, Kanazawa I. Serum anti-GQ1b IgG antibody is associated with ophthalmoplegia in Miller-Fisher syndrome and Guillain-Barré syndrome: Clinical and immunohistochemical studies. Neurol 1993;43:1911-7.

9 Ando S, Yu RK. Isolation and characterization of a novel trisialo ganglioside, GT1a, from human brain. trisialo ganglioside, GT1a,

10 Ueno K, Ando S, Yu RK. Gangliosides of human, cat, and rabbit spinal and cord myelin. $\mathcal{F}$ Lipid Res 1978; 19:863-71.

11 Dawson G, Stefanson K. Gangliosides of human spinal cord: aberrant composition of cords from patients with amyotrophic lateral sclerosis. $\mathcal{f}$ Neuroscience Res 1984; 12:213-20. 